\title{
OBTAINING CANDIDATE SALT TOLERANT WHEAT MUTANT LINES DERIVED FROM COMBINATION OF SODIUM AZIDE MUTAGENESIS AND SOMATIC EMBRYOGENESIS
}

\author{
Ayse $\mathrm{SEN}^{1 *}$, Fatma SARSU ${ }^{2}$ \\ ${ }^{1}$ Department of Biology, Faculty of Science, Istanbul University, 34134, Vezneciler, Istanbul, TURKEY \\ 2 Plant Breeding and Genetics Section, Joint FAO/IAEA Division, Vienna International Centre, PO Box 100, A-1400 \\ Vienna, AUSTRIA \\ *Corresponding author: ORCID ID: orcid.org/0000-0002-1690-4536, e-mail: senayse@istanbul.edu.tr
}

\section{Cite this article as:}

Sen A. \& Sarsu F. 2019. Obtaining Candidate Salt Tolerant Wheat Mutant Lines Derived from Combination of Sodium Azide Mutagenesis and Somatic Embryogenesis. Trakya Univ J Nat Sci, 20(2): 129-134, DOI: 10.23902/trkjnat.571255

\begin{abstract}
Plant mutants are important bio-resources for crop breeding and functional gene studies. In the present study, conventional chemical mutagenesis technique was combined with somatic embryogenesis to obtain candidate salt tolerant mutant wheat lines. For this purpose, 0-5 mM Sodium Azide $\left(\mathrm{NaN}_{3}\right)$ was applied for 30 minutes to embryonic calli under in vitro conditions to produce genetic variations in the bread wheat (Triticum aestivum L. cv. Adana 99). Treated and non-treated calli were put in somatic embryo induction media, and 3 and $4 \mathrm{mM} \mathrm{NaN} 3$ were determined as optimum mutation doses for somatic embryo induction. The obtained somatic embryos from these optimum mutagen doses were then screened for tolerance in regeneration media containing $125 \mathrm{mM} \mathrm{NaCl}$ to be used to improve tolerance to salt stress. In $\mathrm{NaN}_{3}$ treatment, 14 mutants with moderate salt tolerance were obtained. The results suggest that the in vitro technique in combination with chemical mutagenesis may be a useful approach for accelerating breeding strategies to create enough genetic variation in populations and to get fourth generation putative salt tolerant wheat mutant lines in less than 1.5 years.
\end{abstract}

Key words: Sodium azide, in vitro mutagenesis, salt tolerance, somatic embryogenesis, wheat.

Özet: Bitki mutantları, bitki 1slahı ve fonksiyonel gen çalışmaları için önemli biyo-kaynaklardır. Mevcut çalışmada, tuza toleranslı aday mutant buğday hatları elde etmek için somatik embriyogenez ile konvansiyonel kimyasal mutajenez tekniği birleştirildi. Bu amaçla; ekmeklik buğdayda (Triticum aestivum L. cv. Adana 99) genetik varyasyonlar yaratmak için embriyonik kalluslara 0-5 mM Sodyum Azid $\left(\mathrm{NaN}_{3}\right)$, 30 dakika boyunca in vitro ortamda uygulandı. İşlem görmüş ve görmemiş kalluslar, somatik embriyo teşvik ortamına konularak somatik embriyo teşviki için 3 ve $4 \mathrm{mM} \mathrm{NaN}_{3}$ uygulaması optimum mutasyon dozları olarak tespit edildi. Ardından bu mutasyon dozları ile muamele edilen kalluslardan elde edilen somatik embriyolar tuz stresine tolerans geliştirmek için kullanılacak $125 \mathrm{mM} \mathrm{NaCl}$ içeren rejenerasyon ortamlarında tolerans açısından tarandı. $\mathrm{NaN}_{3}$ muamelesinde, orta düzeyde tuza toleransı olan 14 mutant elde edildi. Elde edilen sonuçlar; kimyasal mutagenez ile kombine halde in vitro teknik uygulamasının, popülasyonlarda yeterli genetik varyasyon oluşturmak ve 1.5 yıldan daha az bir sürede dördüncü jenerasyon tuz toleranslı aday buğday mutant hatlarını 1slah sürecini hızlandırarak elde etmek için kullanışlı bir yöntem olabileceğini göstermektedir.

\section{Introduction}

Wheat (Triticum aestivum L.), the world's most important food crop, covers a cultivated land of 219 million hectares at the global level with more that 758 million tons of annual yield production (Hububat Sektör Raporu, 2017). High level of salinity in agricultural soil is one of the brutal environmental factors for many crops and reduces plant growth and productivity due to its toxic effects (Shrivastava \& Kumar 2015), leading to interruption of sustainable agricultural production. The way to minimize this interruption is to increase salt stress tolerances of the crops in question, which is generally achieved through improvement of the crops via breeding techniques. Induced mutation through mutagenic agents, combined with selective breeding strategy is highly efficient for generating crops with improved traits. These mutagenic agents alter genes or break chromosomes. Sodium azide $\left(\mathrm{NaN}_{3}\right)$ is one of the chemical mutagens and has become an important tool to enhance agronomic traits of crops with its easy handling and low cost. Chemical mutagens induce not only loss-of-function or enhanced function mutations, but also mutate genes that confer novel functions (Al-Qurainy \& Khan 2009). Besides the conventional mutation breeding, in vitro mutagenesis is an important tool to generate rapid phenotypic and genotypic variations in plants. Compared with conventional breeding techniques, in vitro mutagenesis 
can overcome some of the limitations, such as lack of screening of effective mutant treatment techniques and production time for mutated plants (He et al. 2009; Wannajindaporn et al. 2014). Chemical mutagen applications are based on somatic embryogenesis, one of the biotechnological techniques widely used in plant breeding for rapid and large scale propagation of mutant population and mutant selection besides disease free in vitro plants (Suprasanna et al. 2012). The present study was performed in order to (i) combine chemical mutagenesis with somatic embryogenesis to create genetic variation to obtain mutant wheat populations, and (ii) to screen the populations for salinity tolerance using combination of in vitro and in vivo techniques.

\section{Materials and Methods}

\section{$\underline{\text { Material }}$}

The bread wheat cultivar Adana-99 (Triticum aestivum L. cv.) was obtained from the Eastern Mediterranean Agricultural Institute in Adana, Turkey. Adana-99 was selected as the cultivar to be studied considering the results of pre-trials which showed that the percentage of plant regeneration from somatic embryos was determined to be high.

Determination of $\mathrm{NaCl}$ threshold concentration for screening salt tolerance

In order to determine threshold $\mathrm{NaCl}$ concentration of the target bread wheat cultivar, its seeds were sterilized and were imbibed in sterile water for 2 hours at $35^{\circ} \mathrm{C}$, and mature embryos were removed under aseptic conditions (Ozgen et al. 1998). The mature embryos were subsequently inoculated in Murashige and Skoog (MS) medium (Murashige \& Skoog 1962) basal salt mixture containing $0.05 \mathrm{mgL}^{-1}$ 2,4-Dichlorophenoxyacetic acid (2.4-D), $20 \mathrm{gL}^{-1}$ sucrose, $0.8 \%(\mathrm{w} / \mathrm{v})$ agar and different concentrations of $\mathrm{NaCl}$ [0 (as a control), 50, 100, 150 and $200 \mathrm{mM} \mathrm{NaCl}$. The $\mathrm{pH}$ of the screening media was adjusted to 5.8 before autoclaving. The cultures were incubated in a growth chamber at $26 \pm 2^{\circ} \mathrm{C}$ for 28 days under 16 hours of light: 8 hours of dark photoperiod and irradiance of $500 \mu \mathrm{mol} \mathrm{m} \mathrm{m}^{-2} \mathrm{~s}^{-1}$ photon flux density. The regeneration ratios, plant heights and fresh weights of the 28-day-old cultures were measured and the screening concentration of $\mathrm{NaCl}$ was selected accordingly.

In vitro mutagenesis and screening mutants for salt tolerance

Callus induction:

The mature embryo explants from sterilized wheat seeds were removed under aseptic conditions as described above and inoculated in petri dishes with a callus induction medium consisted of mineral salts of MS, 2 $\mathrm{mgL}^{-1} 2.4-\mathrm{D}, 20 \mathrm{gL}^{-1}$ sucrose, and $0.8 \%$ (w/v) agar. The $\mathrm{pH}$ was adjusted to 5.8 before autoclaving. The cultures were incubated in a growth chamber at $28 \pm 2^{\circ} \mathrm{C}$ for 21 days under dark conditions.
In vitro mutagenesis, somatic embryo induction, indirect regeneration and in vitro selection:

Three-week-old embryonic calli derived from mature embryos were treated with $\mathrm{NaN}_{3}(\mathrm{pH} 3.5)$ at 0.0 (as a control), 1.0, 2.0, 3.0, 4.0, and $5.0 \mathrm{mM} \mathrm{NaCl}$ concentrations for 30 minutes (He et al. 2009; Wannajindaporn et al. 2014) and then transferred to non-selective medium. After 72 hours of recovery, the calli were transferred to somatic embryo induction medium. The medium was prepared with MS salts, $20 \mathrm{gL}^{-1}$ sucrose, $2 \mathrm{mgL}^{-1}$ 2.4-D, $100 \mathrm{mgL}^{-1}$ myo-inositol, 500 $\mathrm{mgL}^{-1}$ glutamin, $300 \mathrm{mgL}^{-1}$ casein hydrolysate, $1 \mathrm{mlL}^{-1} \mathrm{~B} 5$ vitamin (Gamborg et al. 1968) complex (1000x), and $8 \mathrm{gL}^{-1}$ agar. Its $\mathrm{pH}$ was adjusted to 5.8 before autoclaving. Embryogenic callus and somatic embryo cultures were incubated in a growth chamber at $26^{\circ} \mathrm{C}$ for 4 weeks in dark conditions (Zair et al. 2003). One month later, the ratios of somatic embryo induction were recorded and according to these records, the optimum mutagen dosages were detected to be 3 and $4 \mathrm{mM} \mathrm{NaN}_{3}$. 500 calli were treated with each concentration to create mutant populations. Four weeks later, obtained somatic embryos were transferred to selective indirect regeneration media, which contained MS, $20 \mathrm{gL}^{-1}$ sucrose, $0.5 \mathrm{mgL}^{-1}$ indole-3-acetic acid (IAA), $1 \mathrm{mlL}^{-1} \mathrm{~B} 5$ vitamin complex (1000x), 0 (as a control) and $125 \mathrm{mM} \mathrm{NaCl}$, and $8 \mathrm{gL}^{-1}$ agar, and cultured at $26 \pm 2^{\circ} \mathrm{C}$ under 16 hours of light/ 8 hours of dark photoperiod for two months.

Transferring into soil, acclimating process and segregating the mutant lines up to fourth generation $\left(\mathrm{M}_{1}-\mathrm{M}_{4}\right)$ :

The rooted seedlings of 60-day-old mutant lines and parental line were transferred to pots for acclimation in a greenhouse at a temperature of $25^{\circ} \mathrm{C}$. After acclimation, $\mathrm{NaCl}$ was gradually added to the $1 / 10$ Hoagland Solution (Hoagland \& Arnon 1950) in increasing increments of 25 $\mathrm{mM}$ every week until the salt concentration reached the final treatment level of $125 \mathrm{mM}$. Plantlets were irrigated with two days intervals until anthesis. After anthesis, 1/10 Hoagland Solution was used for irrigation. Once the first generation mutants $\left(\mathrm{M}_{1}\right)$ became 90 days old, their immature seeds were collected and embryos were isolated under aseptic conditions. The immature embryos were transferred to $1 / 2 \mathrm{MS}$ media with $20 \mathrm{gL}^{-1}$ sucrose, $125 \mathrm{mM}$ $\mathrm{NaCl}$ and $8 \mathrm{gL}^{-1}$ agar. The $\mathrm{pH}$ was adjusted to 5.8 before autoclaving. These cultures were incubated in a growth chamber at $26^{\circ} \mathrm{C}$ for 14 days under 16 hours of light/ 8 hours of dark photoperiod. Two-week-old seedlings were transferred to pots. When the second generation mutant lines $\left(\mathrm{M}_{2}\right)$ became 90 days old, the same procedure was applied to generate third and subsequently fourth generation mutant lines $\left(\mathrm{M}_{3}\right.$ and $\left.\mathrm{M}_{4}\right)$. Fig. 1 shows the basic steps of obtaining candidate salt tolerant mutant lines.

\section{Data analyses}

One-way analysis of variance (ANOVA) followed by Student-Newman Keuls post-hoc test was used to make statistical analysis by running SPSS computer program (IBM Inc., Chicago, IL, USA), based on fresh weight and plant height. All values were expressed as mean \pm standard error mean (Zar 1984). 

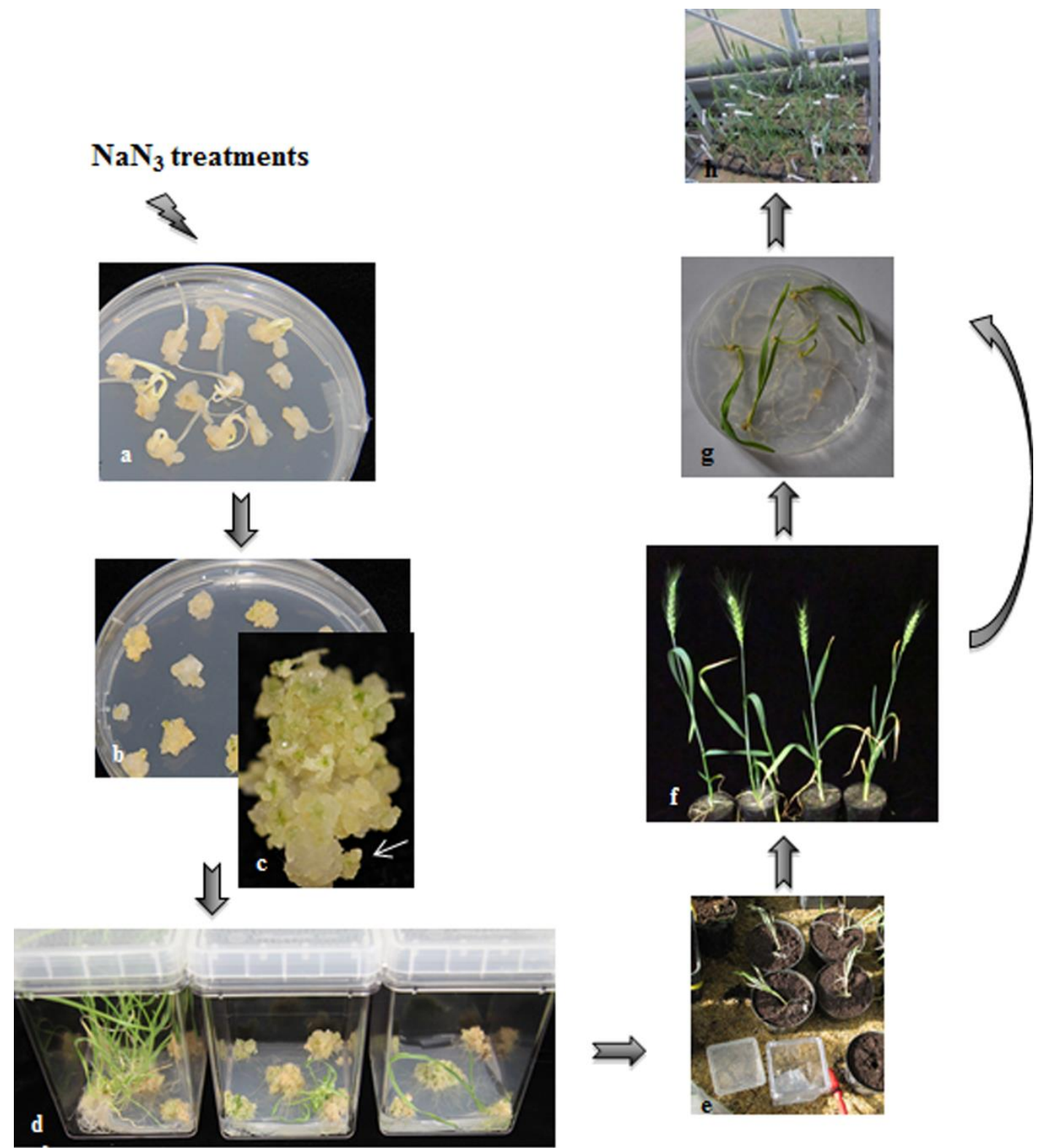

Fig. 1. The basic steps for obtaining candidate salt tolerant wheat mutant lines. Inducing embryonic calli in induction medium and the treating embryonic calli with $\mathrm{NaN}_{3}$ (a), $\mathrm{NaN}_{3}$ treated embryonic calli were to transferred somatic embryo induction medium (b and c), obtained somatic embryos were transferred to indirect regeneration media containing $\mathrm{NaCl}$ (d), the rooted candidate salt-tolerant mutant lines were transferred to pots (e), mutant lines were growth up to setting seeds (f), once the first generation of mutant lines seeds set, their immature embryos were isolated under aseptic conditions and transferred to $1 / 2 \mathrm{MS}$ media with $20 \mathrm{gL}^{-1}$ sucrose, $125 \mathrm{mM} \mathrm{NaCl}$ and $8 \mathrm{gL}^{-1}$ agar for germinations $(\mathrm{g})$. Then, these were two-week-old mutant lines were transferred to pots and grown until plantlets set seeds $(\mathrm{h})$. The steps from $\mathrm{f}$ to $\mathrm{h}$ were repeated four times for fixing genome.

\section{Results}

\section{Determination of threshold $\mathrm{NaCl}$ concentrations}

Table 1 shows that increased salt concentration significantly decreased the regeneration ratio $(16.67-$ $90 \%)$, average plant fresh weight (17.07-81.38\%), and average plant height (11.95-67.92\%). 100 and $150 \mathrm{mM}$ $\mathrm{NaCl}$ concentrations reduced the average plant fresh weight and length approximately by $50 \%-60 \%$ compared to the control. We therefore chose the $100 \mathrm{mM}$ as the threshold concentration and growth media with $125 \mathrm{mM}$ $\mathrm{NaCl}$, which was slightly above the threshold concentration, was used to select the candidate salt tolerant plants.

Determination of mutagen concentration(s) and selection of mutant individuals under in vitro conditions, transferring plantlets into soil and segregating them up to fourth generation

In order to determine optimum mutagen concentration(s), firstly 50 embryonic calli were treated with $\mathrm{NaN}_{3}$ concentrations from 0 to $5 \mathrm{mM}$. Then, these calli were inoculated into somatic embryo induction medium. Somatic embryo induction rates were calculated 
to be $80.00 \%, 85.50 \%, 87.75 \%, 92.31 \%, 93.25 \%$ and $77.30 \%$, under 0 (without $\mathrm{NaN}_{3}$ application), 1, 2, 3, 4 and $5 \mathrm{mM} \mathrm{NaN}_{3}$ treatments, respectively. According to these results, 3 and $4 \mathrm{mM} \mathrm{NaN}_{3}$ concentrations were selected to be optimum mutagen concentrations for creating mutant populations. In the next step, 500 embryonic calli from each concentration were treated with 3 and $4 \mathrm{mM} \mathrm{NaN}_{3}$ and inoculated into somatic embryo induction medium. Then, the generated somatic embryos were put into selective regeneration medium including 0 (as a control) and $125 \mathrm{mM} \mathrm{NaCl}$. These cultures were monitored during two months. In the control group (without $\mathrm{NaN}_{3}$ treatment), 25 plantlets regenerated in the culture of 125 $\mathrm{mM} \mathrm{NaCl}$. Eight of them set seeds under $\mathrm{NaCl}$ treatments. A total of 334 plantlets were obtained under $\mathrm{NaN}_{3}$ treatments. 180 of them showed growth and morphological abnormalities (i.e., sterility, dwarf, awn, and abnormal head morphology) due to either $\mathrm{NaN}_{3}$ or $\mathrm{NaCl}$ treatments. The fertile plantlets were calculated as 154 (91 for $3 \mathrm{mM}$ and 63 for $4 \mathrm{mM} \mathrm{NaN}_{3}$ ) with $125 \mathrm{mM}$ $\mathrm{NaCl}$ treatment.

In order to obtain $\mathrm{M}_{2}$ mutant lines, the first-generation immature embryos from 162, 90-day-old fertile plantlets derived from either somatic variation or $\mathrm{NaN}_{3}$ induction were collected and transferred to $1 / 2 \mathrm{MS}$ media with 125 $\mathrm{mM} \mathrm{NaCl}$ under aseptic conditions to grow the second generation. After two weeks, $101 \mathrm{M}_{2}$ mutant lines were transplanted into greenhouse. The mutant lines were irrigated with $125 \mathrm{mM} \mathrm{NaCl}$ twice a week until full grain filling. Nearly $85 \mathrm{M}_{2}$ mutant lines set seeds. The $\mathrm{M}_{2}$ generation immature embryos from mutant lines were collected and transplanted into pots. Of the 85 mutant lines, 55 were regenerated of which 33 set seeds. When the same experimental procedures were repeated to obtain further generation mutant lines, the number of seed setting plants were recorded as 25 in $\mathrm{M}_{3}$ and 14 in $\mathrm{M}_{4}$ mutants. The distribution of obtained candidate salt tolerant $\mathrm{M}_{4}$ mutant lines are given in Table 2.

In the second generation, no fertile mutant plantlet from somatic variation derived at the first generation mutant plantlets (without $\mathrm{NaN}_{3}$ treatment control plantlets) under $\mathrm{NaCl}$ treatments was recorded. This result creates the impression that $125 \mathrm{mM} \mathrm{NaCl}$ application reduced fertility. Additionally, due to genetic segregations, decreasing in fertility rate was observed in each mutant population under salt application.

Table 1. Regeneration percentages, average fresh plant weights and plant heights of 28-day-old Adana 99 cultivar exposed to different concentrations of $\mathrm{NaCl}$.

\begin{tabular}{|c|c|c|c|c|}
\hline Experimental Groups & Explant Number & Regeneration \% & $\begin{array}{c}\text { Average Plant Fresh } \\
\text { Weight (mg) } \\
\end{array}$ & $\begin{array}{c}\text { Average Plant Height } \\
(\mathbf{c m})\end{array}$ \\
\hline Control & 30 & 90.00 & $709 \pm 13^{a}$ & $14.65 \pm 1.98^{\mathrm{a}}$ \\
\hline $50 \mathrm{mM} \mathrm{NaCl}$ & 30 & 80.00 & $588 \pm 18^{\mathrm{b}^{*}}$ & $12.9 \pm 1.3^{\mathrm{a}}$ \\
\hline $100 \mathrm{mM} \mathrm{NaCl}$ & 30 & 66.67 & $385 \pm 21^{\mathrm{c}^{*}}$ & $8.5 \pm 0.81^{\mathrm{b}^{*}}$ \\
\hline $150 \mathrm{mM} \mathrm{NaCl}$ & 30 & 50.00 & $264 \pm 26^{\mathrm{d}^{* *}}$ & $6.8 \pm 0.87^{\mathrm{c}^{*}}$ \\
\hline $200 \mathrm{mM} \mathrm{NaCl}$ & 30 & 16.67 & $132 \pm 16^{\mathrm{e}^{\mathrm{e} * *}}$ & $4.7 \pm 0.64^{\mathrm{d}^{* *}}$ \\
\hline
\end{tabular}

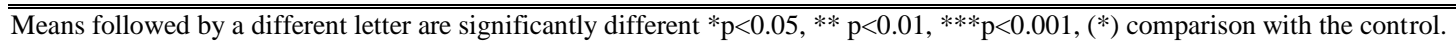

Table 2. $\mathrm{NaN}_{3}$ and $\mathrm{NaCl}$ concentrations $(\mathrm{mM})$ and morphological characteristics of $14 \mathrm{M}_{4}$ wheat mutants.

\begin{tabular}{cccc}
\hline \hline Mutant Lines & NaN $_{\mathbf{3}}(\mathbf{m M})$ & NaCl $(\mathbf{m M})$ & Morphological Characteristics \\
\hline \hline Adn99-1 & 3 & 125 & Normal appearance \\
Adn99-2 & 3 & 125 & Normal appearance \\
Adn99-3 & 3 & 125 & Normal appearance \\
Adn99-4 & 3 & 125 & Earliness \\
Adn99-5 & 3 & 125 & Normal appearance \\
Adn99-6 & 3 & 125 & Normal appearance \\
Adn99-7 & 4 & 125 & Normal appearance \\
Adn99-8 & 4 & 125 & Normal appearance \\
Adn99-9 & 4 & 125 & Normal appearance \\
Adn99-10 & 4 & 125 & Normal appearance \\
Adn99-11 & 4 & 125 & Normal appearance \\
Adn99-12 & 4 & 125 & Normal appearance \\
Adn99-13 & 4 & 125 & Without awn \\
Adn99-14 & 4 & 125 & Different spike morphology \\
\hline \hline
\end{tabular}




\section{Discussion}

Salinity constrains crop growth and agricultural productivity in many regions in the world. It has been estimated that $20 \%$ of the world's irrigated land is affected by salinity (Wang et al. 2003). In Turkey, 3.6 million ha of land are not suitable for farming due to salinity and high subsoil water. More than 1.5 million ha of these lands making almost $2 \%$ of Turkey's total area are saline soils (Kanber et al. 2005). The improvement of salt-tolerant crops would be a practical solution to this problem and different strategies are being developed to serve this solution. In the presented study, we modified in vitro somatic embryogenesis technique combined with $\mathrm{NaN}_{3}$ applications to improve salt tolerance in the Turkish bread wheat cultivar Adana 99. We determined the genetic tolerance capacity of Adana 99 against salinity and our results showed that, in agreement with previous studies (Zair et al. 2003; Yumurtaci \& Uncuoglu 2012), increased $\mathrm{NaCl}$ concentration negatively affected plant growth and $125 \mathrm{mM} \mathrm{NaCl}$ concentration was determined as a selection concentration.

Mutants generated via conventional mutation technology usually take a substantial amount of time and work to screen, especially for large quantities. However, through the combination of in vitro mutation and tissue culture, researchers can rapidly isolate variants with desired agronomic traits (Serrat et al. 2014). In our study, we used $\mathrm{NaN}_{3}$ as a chemical mutagen to induce variations in the embryonic cultures. $\mathrm{NaN}_{3}$, in contrast to natural mutations, generally induces mutation bias on $\mathrm{AT} \rightarrow \mathrm{GC}$ base pair substitutions resulting in amino acid changes, which change the function of proteins and alter phenotypes (Olsen et al. 1993) and is frequently used to create mutant crop genotypes (Al-Qurainy \& Khan 2009). In a study on embryonic calli from immature maize embryos, the treatment of $20 \mathrm{~Gy}$ of gamma ray and $1 \mathrm{mmolL}^{-1}$ of $\mathrm{NaN}_{3}$ was identified as the most effective for inducing mutation (He et al. 2009). Ganesan et al. (2005) showed that somatic embryo germination in cotton increased from $44.6 \%$ to $50.9 \%$ with a $10 \mathrm{mM} \mathrm{NaN}_{3}$ treatment. Ikram-ul-Haq et al. (2011) used $0.5 \% \mathrm{NaN}_{3}$ at $\mathrm{pH} 4.6-4.7$ to induce mutation in sugarcane calli to obtain salt-tolerant mutants. Ahmad et al. (2010) used 0.0-0.5 $\mathrm{mM} \mathrm{NaN}_{3}$ to induce mutation in potato calli. In our study, 3 and $4 \mathrm{mM} \mathrm{NaN}_{3}$ concentrations were selected as the optimum mutagen concentrations for creating mutant populations because these concentrations increased the frequency of somatic embryo formation.

\section{References}

1. Ahmad, I., Nasir, I.A., Saleem, M., Haider, M., Javed, M.A., Javed, M.A., Latif, Z. \& Husnain, T. 2010. In vitro induction of mutation in potato cultivars. Pakistan Journal of Phytopathology, 22(1): 51-57.

2. Al-Qurainy, F. \& Khan, S. 2009. Mutagenic effects of sodium azide and its application in crop improvement. World Applied Sciences Journal, 6(12): 1589-1601.
Plant breeding for determination of tolerance to salt stress requires reliable and rapid screening techniques. Screening in field conditions is difficult due to various factors such as stress heterogeneity, the presence of other soil-related stresses, temperature, relative humidity and solar radiation. However, a laboratory-based in vitro strategy can increase genetic variation and is the easiest way to screen large cell populations in a short time and on a year-round basis. Somatic embryogenesis is one of the regeneration methods by which somatic embryos arise from single cells and an efficient method of plant regeneration allowing rapid production of large number of "true to type " plants. Each mutated single cell can develop into a somatic embryo and regenerate a mutant plant. The combination of in vitro mutation with conventional breeding as well as in vitro selection increased the variation of genetic diversity that produced a superior variety in a recent genetic diversification program (Jain 2010). In vitro mutagenesis strategies have been used for different plants. Wannajindaporn et al. (2014) reported that 28 Dendroium'Earsakul'mutants were obtained with protocorm-like bodies using 0-5 mM $\mathrm{NaN}_{3}$ under in vitro conditions. Abiotic and biotic stresstolerant mutants have been obtained by applying chemical mutagens coupled with in vitro systems in chrysanthemum (salt), sugarcane (salt), banana (drought) and banana (viruses) (Hossain et al. 2006; Ikram-ul-Haq et al. 2011; Bidabadi et al. 2011; El-Sayed et al. 2012). The general strategy in breeding is that segregating the offspring, whose genomes have been modified such a kind of techniques mutagen applications or hybridizations, at least six generations are needed to fix their modified genomes. In this study, 14 fourthgeneration candidate salt tolerant mutant lines were obtained with combination of somatic embryogenesis approach with $125 \mathrm{mM} \mathrm{NaCl}$ application. The study is still continuing to stabilize the mutated genome gained by the new character.

In conclusion, the results suggest that the in vitro technique in combination with chemical mutagenesis may be a useful approach for accelerating breeding strategies to create enough genetic variation in populations and to get fourth generation candidate salt tolerant wheat mutant lines in less than 1.5 years.

\section{Acknowledgement}

This study was supported by The Research Fund of Istanbul University by Project Numbers: FBA-201724750, BEK-2017-24939, 31725, BYP-2018-32759 and 49463 to AS.

3. Bidabadi, S.S., Mahmood, M., Meon, S., Wahab, Z. \& Ghobadi, C. 2011. Evaluation of in vitro water stress tolerance among EMS -induced variants of banana (Musa spp., AAA), using morphological, physiological and molecular traits. Journal of Crop Science and Biotechnology, 14: 255-263. 
4. El-Sayed, E.H., Mahfouze, S.A., Shaltout, A.D., ElDougdoug, K.A. \& Sayed, R.A. 2012. Chemical mutation induction in vitro cultured shoot tip of banana cv. Grand Nain and for resistance some virus diseases. International Journal of Virology, 8: 178-190.

5. Gamborg, O.L., Miller, R.A. \& Ojima, K. 1968. Nutrient requirements of suspension cultures of soybean root cells. Experimental Cell Research, 50: 151-158.

6. Ganesan, M., Bhanumathi, P. \& Jayabalan, N. 2005. Mutagenic effect of sodium azide on somatic embryo regeneration and root growth of cotton (Gossypium hirsutum L. CV. SVPR2). Journal of Agricultural Technology, 365-380.

7. He, J., Hu, Y., Li, W.C. \& Fu, F.L. 2009. Drought tolerant mutant induced by gamma-ray and sodium azide from maize calli. Maize Genetics Cooperation Newsletter, 83: 53-55.

8. Hoagland, D.R. \& Arnon, D.I. 1950. The Water Culture Method For Growing Plant Without Soil. University of California Berkley Press, CA, 347 pp.

9. Hossain, Z., Mandal, A.K., Datta, S.K. \& Biswas, A.K. 2006. Development of NaCl-tolerant strain in Chrysanthemum morifolium Ramat. through in vitro mutagenesis. Plant Biology, 8: 450-461.

10. Hububat Sektör Raporu 2017. http://www.tmo.gov.tr/Upload/Document/hububatsektorra poru2017.pdf (Date accessed: 6.05.2019)

11. ul-Haq, I., Memon, S., Gill, N.P. \& Rajput, M.T. 2011. Regeneration of plantlets under $\mathrm{NaCl}$ stress from $\mathrm{NaN}_{3}$ treated sugarcane explants. African Journal of Biotechnology, 10: 16152-16156.

12. Jain, M.S. 2010. Mutagenesis in crop improvement under the climate change. Romanian Biotech Letter, 15: 88-106.

13. Kanber, R., Çullu, M.A., Kendirli, B., Antepli, S. \& Y1lmaz, N. 2005. Sulama, drenaj ve tuzluluk, 213-251. Paper presented at the Türkiye Ziraat Mühendisliği 6 . Teknik Kongresi, Cilt I, 3-7 Ocak, Ankara-Turkey.

14. Murashige, T. \& Skoog, F. 1962. A revised medium for rapid growth and bioassays with tobacco tissue cultures. Physiologia Plantarum, 15: 473-497.
15. Olsen, O., Wang, X. \& Von Wetttesin, D. 1993. Sodium azide mutagenesis: Preferential generation of AT $\rightarrow$ GC transitions in the barley Antl8 gene. Proceedings of the National Academy of Sciences of the United States of America, 90: 8043-8047.

16. Ozgen, M., Turet, M., Altinok, S. \& Sancak, C. 1998. Effects callus induction and plant regeneration from mature embryo culture of winter wheat (Triticum aestivum L.) genotypes. Plant Cell Reporter, 18: 331-335.

17. Serrat, X., Esteban, R., Guibourt, N., Moysset, L., Nogués, S. \& Lalanne, E. 2014. EMS mutagenesis in mature seedderived rice calli as a new method for rapidly obtaining TILLING mutant populations. Plant Methods, 10(1): 5.

18. Shrivastava, P. \& Kumar, R. 2015. Soil salinity: A serious environmental issue and plant growth promoting bacteria as one of the tools for its alleviation. Saudi Journal of Biological Sciences, 22: 123-131.

19. Suprasanna, P., Jain, S.M., Ochatt, S.J., Kulkarni, V.M. \& Predieri, S. 2012. Application of in vitro techniques in mutation breeding of vegetatively propagated crop. Pp. 371-385. In: Shu, Q.Y., Forster, B.P. \& Nakagawa, H. (eds) Plant Mutation Breeding and Biotechnology. Join FAO/IAEA Programme Nuclear Techniques in Food and Agriculture, $595 \mathrm{pp}$.

20. Wang, W. Vinocur, B. \& Altman, A. 2003. Plant responses to drought, salinity and extreme temperatures: towards genetic engineering for stress tolerance. Planta, 218: 1-14.

21. Wannajindaporn, A., Poolsawat, O., Chaowiset, W. \& Tantasawat, P.A. 2014. Evaluation of genetic variability in in vitro sodium azide-induced Dendrobium 'Earsakul' mutants. Genetics and Molecular Research, 13: 53335342.

22. Yumurtaci, A. \& Uncuoglu, A.A. 2012. Tissue specific responses alter the biomass accumulation in wheat under gradual and sudden salt stress. Journal of Stress Physiology and Biochemistry, 8: 143-156.

23. Zair, I., Chlyah, A., Sabounji, K., Tittahsen, M. \& Chlyah, H. 2003. Salt tolerance improvement in some wheat cultivars after application of in vitro selection pressure. Plant Cell Tissue and Organ Culture, 73: 237-244.

24. Zar, J.H. 1984. Biostatistical Analysis. Prentice-Hall Inc., Englewood Cliffs, Jersey, 620 pp. 